Article

\title{
Synthesis and Cytotoxicity Evaluation of 13-n-Alkyl Berberine and Palmatine Analogues as Anticancer Agents
}

\author{
Lei Zhang ${ }^{1}$, Jingjing Li ${ }^{1}$, Fei Ma ${ }^{2,3}$, Shining Yao ${ }^{4}$, Naisan Li ${ }^{1}$, Jing Wang ${ }^{1}$, Yongbin Wang ${ }^{1}$, \\ Xiuzhen Wang ${ }^{5}$ and Qizheng Yao ${ }^{1, *}$
}

1 School of Pharmacy, China Pharmaceutical University, Nanjing 210009, Jiangsu, China;

E-Mails: zhanglei04402@163.com (L.Z.); leejingjing119@yahoo.com.cn (J.L.); linaisan@vip.sina.com (N.L.); wangjing0642320@126.com (J.W.); wybhzsyq@126.com (Y.W.)

2 Oil Crops Research Institute, Chinese Academy of Agricultural Sciences, Wuhan 430062, Hubei, China; E-Mail: mafeicpu@163.com

3 Key Laboratory of Biology and Genetic Improvement of Oil Crops, Ministry of Agriculture, Wuhan 430062, Hubei, China

4 Wuxi JC Pharmaceutical Technology Inc., Wuxi 214036, Jiangsu, China; E-Mail:yao_sn@yahoo.com.cn

5 School of Pharmacy, Nanjing Medical University, Nanjing 210029, Jiangsu, China; E-Mail: showshow828@163.com

* Author to whom correspondence should be addressed; E-Mail: qz_yao@yahoo.com.cn; Tel./Fax: +86-025-8663-4730.

Received: 30 August 2012; in revised form: 11 September 2012 / Accepted: 17 September 2012 / Published: 25 September 2012

\begin{abstract}
By introducing long carbon-chain alkyl groups at the $\mathrm{C}-13$ position of berberine and palmatine, 13-n-hexyl/13-n-octyl berberine and palmatine chloride analogues $4 \mathbf{a}-\mathbf{d}$ were synthesized and examined by MTT assays for cytotoxic activity in seven human cancer cell lines (7701QGY, SMMC7721, HepG2, CEM, CEM/VCR, KIII, Lewis), yielding $\mathrm{IC}_{50}$ values of $0.02 \pm 0.01-13.58 \pm 2.84 \mu \mathrm{M}$. 13- $n$-Octyl palmatine (compound 4d) gave the most potent inhibitor activity, with an $\mathrm{IC}_{50}$ of $0.02 \pm 0.01 \mu \mathrm{M}$ for SMMC7721. In all cases, the 13- $n$-alkyl berberine and palmatine analogues $4 \mathbf{a}-\mathbf{d}$ were more cytotoxic than berberine and palmatine. In addition, compounds $\mathbf{4 a - d}$ also exhibited more potent cytotoxicity than berberine and palmatine in mice with S180 sarcoma xenografted in vivo. The primary screening results indicated that the 13- $n$-hexyl/13- $n$-octyl berberine and palmatine analogues might be valuable source for new potent anticancer drug candidates.
\end{abstract}


Keywords: berberine; palmatine; alkylation; cytotoxicity; antitumor

\section{Introduction}

Berberine (1a, Figure 1), an isoquinoline alkaloid isolated from the roots and stem bark of Berberis species, is widely used as a traditional medicine for treating diarrhea [1] and gastrointestinal disorders [2].

Figure 1. Structures of the lead compounds $\mathbf{1 a}$ and $\mathbf{1 b}$.

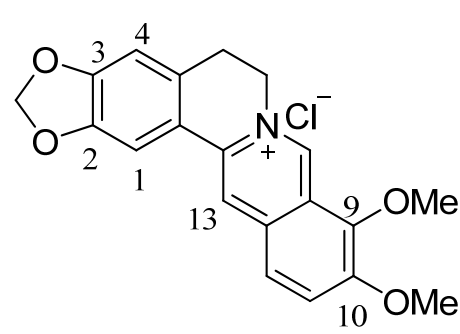

1a

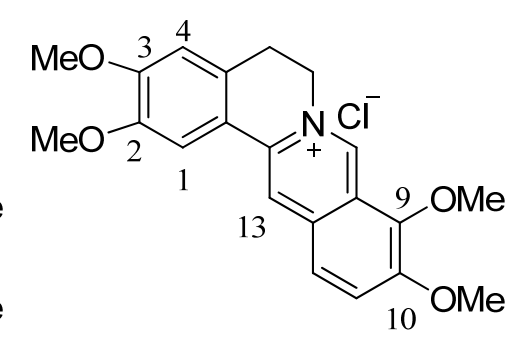

$1 \mathbf{b}$

Berberine possesses various biological activities like antibacterial [3,4], antifungal [5], antimalarial [6], antileishmanial [7], anticancer [8-12], anti-Alzheimer's disease [13,14], antiviral [15,16], cholesterol lowering effect [17] and hypoglycemic effect [18]. Different activities of a number of 8-, 9- and 13-substituted analogues of berberine have been reported. Various analogs using different chain lengths and terminal amino groups have been synthesized to study the DNA-binding affinity or as G-quadruplex stabilizing ligands [19-26].

In addition, palmatine (1), Figure 1) is a close structural analog of berberine. The alkaloid has been used in the treatment of jaundice, dysentery, hypertension, inflammation, and liver-related diseases [27]. It has been reported that like berberine, some of the 8- and 13-alkyl analogues of palmatine also possess antimicrobial and antimalarial activities [28]. Palmatine also has significant antitumor activity against HL-60 leukemic cells [29].

In this study, berberine and palmatine analogues were first designed and synthesized by means of the introduction of long carbon-chain alkyl at carbon atom C-13 to improve the antiproliferative activity in vitro and in vivo.

\section{Results and Discussion}

\subsection{Chemistry}

The synthesis of the 13-n-alkyl substituted berberine and palmatine analogues involved two steps (Scheme 1). Treatment of commercially available berberine (1a) or palmatine (1b) with $\mathrm{NaBH}_{4}$ in $5 \%$ $\mathrm{NaOH}$ at room temperature gave the key reduced intermediates $\mathbf{2 a}, \mathbf{b}$, the dihydrogenated products of 1a and 1b [30]. Then, compounds $2 \mathbf{a}, \mathbf{b}$ were reacted with $n$-hexyl aldehyde (3a) and $n$-octyl aldehyde (3b), respectively, in a EtOH and HOAc solvent mixture, and then acidified with $2 \mathrm{~mol} / \mathrm{L} \mathrm{HCl}$ to yield the desired compounds $\mathbf{4 a - d}$, which were fully characterized by ${ }^{1} \mathrm{H}-\mathrm{NMR}$, LR-MS and elemental analysis. 
Scheme 1. Synthesis of the 13-n-alkyl substituted berberine and palmatine analogues $\mathbf{4 a - d}$.<smiles>[R]c1cc2c(cc1[R])-c1cc3ccc(OC)c(OC)c3c[n+]1CC2</smiles>

1a or $1 \mathbf{b}$<smiles>[R]c1cc2c(cc1[R])C1=Cc3ccc(OC)c(OC)c3CN1CC2</smiles>

$2 \mathbf{a}$ or $\mathbf{2 b}$<smiles>[R]c1cc2c3ncc4c(OC)c(OC)ccc4c([R3])c-3[n+](Cl)c2cc1[R]</smiles>

\begin{tabular}{cccc} 
& $\mathrm{R}_{1}$ & $\mathrm{R}_{2}$ & $\mathrm{R}_{3}$ \\
\hline $\mathbf{4 a}$ & \multicolumn{2}{c}{$\mathrm{OCH}_{2} \mathrm{O}$} & $n-\mathrm{C}_{6} \mathrm{H}_{13}$ \\
$\mathbf{4 b}$ & $\mathrm{OCH}_{2} \mathrm{O}$ & $n-\mathrm{C}_{8} \mathrm{H}_{17}$ \\
$\mathbf{4 c}$ & $\mathrm{OMe}$ & $\mathrm{OMe}$ & $n-\mathrm{C}_{6} \mathrm{H}_{13}$ \\
$\mathbf{4 d}$ & $\mathrm{OMe}$ & $\mathrm{OMe}$ & $n-\mathrm{C}_{8} \mathrm{H}_{17}$
\end{tabular}

Reagents and conditions: (a) $\mathrm{NaBH}_{4}, 5 \% \mathrm{NaOH}$, r.t; (b) $n$-hexyl aldehyde (3a) or $n$-octyl aldehyde (3b), $80 \% \mathrm{EtOH}$, reflux, then acidified with $2 \mathrm{~mol} / \mathrm{L} \mathrm{HCl}$.

\subsection{Biology}

\subsubsection{In Vitro Cytotoxic Effects}

The cytotoxicity of berberine and palmatine and the herein presented analogues $\mathbf{4 a}-\mathbf{d}$ were compared by means of a colorimetric microculture assay (MTT assay) in seven human cancer cell lines: 7701QGY, SMMC7721, HepG2 (human hepatoma), CEM (human acute lymphoblastic leukemia), CEM/VCR (vincristine-resistant CEM), K III (mice melanoma) and Lewis (mice lung carcinoma), yielding $\mathrm{IC}_{50}$ values mostly in the low micromolar or even submicromolar range (Table 1).

Table 1. Cytotoxicity of berberine and palmatine analogues $\mathbf{4 a - d}$ compared with berberine and palmatine in various cancer cell lines.

\begin{tabular}{cccccccc}
\hline Comp. & \multicolumn{7}{c}{ IC $_{\mathbf{5 0}}(\boldsymbol{\mu M M})^{\mathbf{a}}$} \\
\cline { 2 - 8 } & $\mathbf{7 7 0 1 Q G Y}$ & $\mathbf{S M M C 7 7 2 1}$ & HepG2 & CEM & CEM/VCR & K III & Lewis \\
\hline $\mathbf{4 a}$ & $3.28 \pm 0.27$ & $0.37 \pm 0.07$ & $4.74 \pm 0.48$ & $3.64 \pm 0.35$ & $9.65 \pm 2.37$ & $25.47 \pm 2.95$ & $2.26 \pm 0.49$ \\
$\mathbf{4 b}$ & $1.79 \pm 0.26$ & $0.04 \pm 0.02$ & $3.16 \pm 0.39$ & $0.37 \pm 0.03$ & $5.19 \pm 0.64$ & $13.58 \pm 2.84$ & $0.86 \pm 0.10$ \\
$\mathbf{4 c}$ & $10.09 \pm 1.98$ & $0.68 \pm 0.05$ & $5.54 \pm 0.24$ & $1.97 \pm 0.09$ & $17.54 \pm 1.98$ & $30.58 \pm 1.69$ & $2.86 \pm 0.54$ \\
$\mathbf{4 d}$ & $1.08 \pm 0.25$ & $0.02 \pm 0.01$ & $2.28 \pm 0.37$ & $0.16 \pm 0.11$ & $4.80 \pm 0.81$ & $10.41 \pm 2.58$ & $0.34 \pm 0.09$ \\
berberine & $22.18 \pm 1.12$ & $2.09 \pm 0.25$ & $117.63 \pm 3.13$ & $45.04 \pm 1.42$ & $120.37 \pm 3.84$ & $84.29 \pm 3.42$ & $20.29 \pm 4.42$ \\
palmatine & $\mathrm{ND}$ & $23.19 \pm 1.21$ & $\mathrm{ND}$ & $5.68 \pm 0.27$ & $230.76 \pm 5.21$ & $74.13 \pm 4.50$ & $30.18 \pm 2.76$ \\
\hline
\end{tabular}

$\mathrm{ND}=$ not determined. ${ }^{\mathrm{a}} 50 \%$ inhibitory concentrations in the MTT assay ( $72 \mathrm{~h}$ exposure). Values are means standard deviations obtained from at least two (mostly three) independent experiments.

13- $n$-Hexyl/13-n-octyl berberine and palmatine analogues $\mathbf{4 a - d}$ exhibited more potent cytotoxicity than berberine and palmatine in all seven cell lines. 13-n-octyl-berberine (4b) and 13- $n$-octyl-palmatine (4d) exerted the most potent antitumor activities, with $\mathrm{IC}_{50}$ values of $0.02 \pm 0.01-13.58 \pm 2.84 \mu \mathrm{M}$ against various cancer cell lines, and 6-fold stronger antitumor activities than berberine and palmatine. Notably, compound $4 \mathbf{d}$ gave the most potent inhibitor activity, with an $\mathrm{IC}_{50}$ of $0.02 \pm 0.01 \mu \mathrm{M}$ for SMMC7721. Compared with the lead compounds, berberine analogues $\mathbf{4 a , b}$ showed similar activity to palmatine analogues $\mathbf{4 c}$,d, which exhibited more potent activity against CEM and CEM/VCR cells 
(vincristine-resistant) lines. These results indicate that the alkylation of the natural products, berberine and palmatine, such as introduction of longer carbon-chain alkyl groups at the C-13-position, can remarkably enhance the antitumor activity. This modification is likely to make the compounds more lipophilic, which may increase the permeability of the cell membrane and improve the bioavailability of the lead compounds. Very recently, the new insights into 13-position substitution of berberine in enhancing the DNA binding had been reported by Kumar and colleagues [26], suggesting that 13- $n$-hexyl/13-n-octyl berberine and palmatine analogues may enhance the DNA binding action. The further investigation whether the long carbon-chain substituted berberines and palmatines could enhance the DNA binding action to generate more potent antitumor activity will be reported in due course.

\subsubsection{In Vivo Anticancer Activity}

Anticancer activity in vivo was investigated in the murine sarcoma S180 xenografted model on male Kunming mice using intraperitoneal (ip) injection using berberine, palmatine and cyclophosphamide (CP) as the positive control (Table 2).

Table 2. Tumor inhibitory rate of berberine and palmatine and their analogues $\mathbf{4 a - d}$ in the murine sarcoma S180 xenografted model.

\begin{tabular}{|c|c|c|c|c|c|c|c|c|}
\hline \multirow[t]{2}{*}{ Comp. } & \multirow{2}{*}{$\begin{array}{c}\text { Dose } \\
\mathrm{mg} / \mathrm{kg}\end{array}$} & \multirow[t]{2}{*}{ Injection } & \multicolumn{2}{|c|}{ Number of mice } & \multicolumn{2}{|c|}{ Weight of mice (g) } & \multirow{2}{*}{$\begin{array}{l}\text { Weight of } \\
\text { tumor } \\
X \pm \text { SD (g) }\end{array}$} & \multirow{2}{*}{$\begin{array}{c}\text { Tumor } \\
\text { inhibitory } \\
\text { rate }(\%)\end{array}$} \\
\hline & & & Start & End & Start & End & & \\
\hline Control & - & iv & 10 & 10 & $19.48 \pm 1.45$ & $22.19 \pm 2.20$ & $2.20 \pm 0.93$ & - \\
\hline $\mathbf{C P}$ & 30 & iv & 10 & 10 & $20.23 \pm 1.25$ & $20.81 \pm 2.31$ & $0.43 \pm 0.28 * *$ & 80.61 \\
\hline berberine & 30 & ip & 10 & 9 & $20.20 \pm 1.26$ & $17.66 \pm 3.24$ & $1.26 \pm 0.54 * *$ & 42.99 \\
\hline \multirow{2}{*}{$4 a$} & 1 & ip & 10 & 9 & $19.98 \pm 1.33$ & $17.86 \pm 2.25$ & $1.32 \pm 0.63 * *$ & 40.00 \\
\hline & 2.5 & ip & 10 & 6 & $19.62 \pm 1.52$ & $18.04 \pm 2.54 *$ & $1.01 \pm 0.48 * *$ & 54.09 \\
\hline \multirow{2}{*}{$4 b$} & 1 & ip & 10 & 8 & $20.20 \pm 2.22$ & $19.17 \pm 1.12$ & $1.02 \pm 0.25 * *$ & 53.52 \\
\hline & 2.5 & ip & 10 & 5 & $19.89 \pm 1.54$ & $17.11 \pm 1.06$ & $0.88 \pm 0.28 * *$ & 59.86 \\
\hline palmatine & 30 & ip & 10 & 10 & $20.56 \pm 2.03$ & $20.95 \pm 2.18$ & $1.45 \pm 0.31 * *$ & 34.09 \\
\hline \multirow{2}{*}{$4 c$} & 5 & ip & 10 & 10 & $20.33 \pm 1.28$ & $20.45 \pm 1.45$ & $1.43 \pm 0.44 * *$ & 34.88 \\
\hline & 10 & ip & 10 & 9 & $19.16 \pm 1.21$ & $18.88 \pm 2.60 *$ & $1.16 \pm 0.44 * *$ & 47.40 \\
\hline \multirow{2}{*}{$4 d$} & 5 & ip & 10 & 9 & $20.72 \pm 1.45$ & $19.15 \pm 2.75$ & $1.28 \pm 0.38 * *$ & 42.05 \\
\hline & 10 & ip & 10 & 5 & $20.04 \pm 1.57$ & $18.63 \pm 3.20$ & $1.08 \pm 0.42 * *$ & 50.96 \\
\hline
\end{tabular}

SD: standard deviation; $* p<0.05$ vs. model group; $* * p<0.01$ vs. model group.

As listed in Table 2, most of the 13-n-hexyl/13-n-octyl berberines and palmatines showed stronger antitumor activity and higher toxicity than their parent compounds, respectively. The 13-n-octyl isoquinoline alkaloid derivatives $\mathbf{4 b}, \mathbf{d}$ exhibited more activity than the corresponding 13- $n$-hexyl derivatives 4a,c. Among them, compound $4 \mathbf{b}$ possessed the topmost antitumor activity, achieving a tumor inhibitory rate (TIR) of $59.86 \%$ at a dose of $2.5 \mathrm{mg} / \mathrm{kg}$ and showed better dose-efficacy relationship. Whereas compound $\mathbf{4 a}, \mathbf{b}$ and $\mathbf{d}$ had perspicuously higher toxicity than berberine, palmatine and $\mathrm{CP}$, and produced marked decreases in body weight and even the emergence of the phenomenon of death. 
By reducing the dose, the toxic effect of the evaluated compounds can be decreased and their inhibition rate also dropped less. This preliminary in vivo test results showed compound $\mathbf{4 c}$ had good TIR and lower toxicity, indicating that it may have potential clinical value for treating cancer. Forthermore, Chen demonstrated the 13-hexyl-berberine gel could achieve effective anti-HSV (herpes simplex virus) concentrations in the dermis and it was safe to use [31]. The deep study on the administration routes and formulations of $13-n$-alkyl berberine and palmatine analogues will be carried out.

\section{Experimental}

\subsection{General}

All melting points were measured on a Büchi melting point B-540 apparatus (Büchi Labortechnik, Flawil, Switzerland) and were uncorrected. Mass spectra (MS) were taken in ESI model on Agilent 1100 LC-MSD (Agilent, Palo Alto, CA, USA). ${ }^{1}$ H-NMR spectroscopy was performed using a Bruker ARX-300 instrument (Bruker, Fällanden, Switzerland), operating at $300 \mathrm{MHz}$ with TMS as an internal standard. The chemical shifts were reported in ppm $(\delta)$ and coupling constants $(J)$ values were given in Hertz (Hz). Signal multiplicities were represented by: s (singlet), d (doublet), dd (double doublet), $\mathrm{t}$ (triplet), dt (triple triplet), m (multiplet). Elemental analysis was performed by an Elementar Vario EL III instrument (Heraeus $\mathrm{GmbH}$, Hanau, Germany) for $\mathrm{C}, \mathrm{H}$, and $\mathrm{N}$ and the results were within $\pm 0.5 \%$ of the theoretical values. Unless noted otherwise, all solvents and reagents were commercially available and used without further purification.

\subsection{Chemistry: General Procedure for the Synthesis of Compounds $\mathbf{4 a - d}$}

To a stirred solution of $\mathbf{1 a}$ or $\mathbf{1 b}(13.4 \mathrm{mmol})$ in $5 \% \mathrm{NaOH}$ solution $(100 \mathrm{~mL}), 5 \% \mathrm{NaOH}(50 \mathrm{~mL})$ solution containing $\mathrm{NaBH}_{4}(13.4 \mathrm{mmol})$ was added dropwise. The reaction mixture was stirred at room temperature for $3 \mathrm{~h}$ and the precipitated product was filtered, washed with $60 \%$ ethanol $(20 \mathrm{~mL})$, and then recrystallized from absolute ethanol to provide $\mathbf{2 a}$ or $\mathbf{2 b}$ as a brownlike solid. To a stirred solution of $\mathbf{2 a}$ or $\mathbf{2 b}(5.0 \mathrm{mmol})$ in $80 \%$ ethanol $(8 \mathrm{~mL})$ and HOAc $(2 \mathrm{~mL})$, aldehyde $\mathbf{3 a}$ or $\mathbf{3 b}(5.0 \mathrm{mmol})$ was added. The reaction mixture was heated to $85-95{ }^{\circ} \mathrm{C}$ for $5 \mathrm{~h}$. The solvent was removed by evaporation, and the residue was acidified with $2 \mathrm{~mol} / \mathrm{L} \mathrm{HCl}(5 \mathrm{~mL})$, then stirred at room temperature for $1 \mathrm{~h}$. The solid was collected by filtration and then purified by flash chromatography over silica gel, affording the title compounds $\mathbf{4 a -} \mathbf{d}$ as yellow powders.

2,3-Methylenedioxy-9,10-dimethoxy-13-n-hexylprotoberberine chloride (4a). Yield 65\%; m.p. 192-193 ${ }^{\circ} \mathrm{C}$; ${ }^{1} \mathrm{H}-\mathrm{NMR}\left(\mathrm{CDCl}_{3}\right): \delta$ (ppm) 10.66 (s, 1H, Py-H), 7.87-7.94 (m, 2H, Ph-H), 7.12 (s, 1H, Ph-H), 6.90 (s, 1H, Ph-H), $6.11\left(\mathrm{~s}, 2 \mathrm{H},-\mathrm{OCH}_{2}-\right), 5.28-5.33\left(\mathrm{~m}, 2 \mathrm{H},-\mathrm{CH}_{2}-\right), 4.33$ (s, 3H, $\left.-\mathrm{OCH}_{3}\right), 4.09$ (s, 3H, $\left.-\mathrm{OCH}_{3}\right), 3.26-3.31\left(\mathrm{~m}, 2 \mathrm{H},-\mathrm{CH}_{2}-\right), 3.14-3.18\left(\mathrm{~m}, 2 \mathrm{H},-\mathrm{CH}_{2}-\right), 1.83-1.88\left(\mathrm{~m}, 2 \mathrm{H},-\mathrm{CH}_{2}-\right), 1.47-1.54$ (m, 2H, $\left.-\mathrm{CH}_{2}-\right), 1.34-1.39\left(\mathrm{~m}, 4 \mathrm{H},-\mathrm{CH}_{2}^{-}\right), 0.92$ (t, 3H, J=7.0 Hz, $\left.-\mathrm{CH}_{3}\right)$; ESI-MS m/z: 420.1 [M-Cl] ; Anal. calcd. for $\mathrm{C}_{26} \mathrm{H}_{30} \mathrm{ClNO}_{4} \times 1 / 2 \mathrm{H}_{2} \mathrm{O}$ : C 67.16, H 6.72, N 3.01; found: C 67.21, H 6.68, N 3.01.

2,3-Methylenedioxy-9,10-dimethoxy-13-n-octylprotoberberine chloride (4b). Yield 56\%; m.p. 188-189 ${ }^{\circ} \mathrm{C} ;{ }^{1} \mathrm{H}-\mathrm{NMR}\left(\mathrm{CDCl}_{3}\right): \delta$ (ppm) 10.59 (s, 1H, Py-H), 7.79-7.86 (m, 2H, Ph-H), 7.04 (s, 1H, $\mathrm{Ph}-\mathrm{H}), 6.83(\mathrm{~s}, 1 \mathrm{H}, \mathrm{Ph}-\mathrm{H}), 6.04\left(\mathrm{~s}, 2 \mathrm{H},-\mathrm{OCH}_{2}-\right), 5.19-5.24\left(\mathrm{~m}, 2 \mathrm{H},-\mathrm{CH}_{2}-\right), 4.28\left(\mathrm{~s}, 3 \mathrm{H},-\mathrm{OCH}_{3}\right), 4.02$ 
$\left(\mathrm{s}, 3 \mathrm{H},-\mathrm{OCH}_{3}\right), 3.17-3.22\left(\mathrm{~m}, 2 \mathrm{H},-\mathrm{CH}_{2}-\right), 3.07-3.12\left(\mathrm{~m}, 2 \mathrm{H},-\mathrm{CH}_{2}-\right), 1.78-1.81\left(\mathrm{~m}, 2 \mathrm{H},-\mathrm{CH}_{2}-\right), 1.43-1.46$ (m, $\left.2 \mathrm{H},-\mathrm{CH}_{2}-\right), 1.11-1.16\left(\mathrm{~m}, 8 \mathrm{H},-\mathrm{CH}_{2}-\right), 0.81\left(\mathrm{t}, 3 \mathrm{H}, J=7.0 \mathrm{~Hz},-\mathrm{CH}_{3}\right)$; ESI-MS $m / z: 448.1$ [M-Cl] $]^{+}$; Anal. calcd. for $\mathrm{C}_{28} \mathrm{H}_{34} \mathrm{ClNO}_{4} \times 3 / 4 \mathrm{H}_{2} \mathrm{O}$ : C 67.59, H 7.19, N 2.82; found: C 67.69, H 7.15, N 2.68.

2,3-Dimethoxy-9,10-dimethoxy-13-n-hexylprotoberberine chloride (4c). Yield 64\%; m.p. 180-182 ${ }^{\circ} \mathrm{C}$; ${ }^{1} \mathrm{H}-\mathrm{NMR}\left(\mathrm{CDCl}_{3}\right): \delta$ (ppm) 10.89 (s, 1H, Py-H), 7.89-7.95 (m, 2H, Ph-H), 7.26 (s, 1H, Ph-H), 6.96 (s, 1H, Ph-H), 5.20-5.25 (m, 2H, - $\left.\mathrm{CH}_{2}-\right), 4.39\left(\mathrm{~s}, 3 \mathrm{H},-\mathrm{OCH}_{3}\right), 4.16\left(\mathrm{~s}, 3 \mathrm{H},-\mathrm{OCH}_{3}\right), 4.06\left(\mathrm{~s}, 3 \mathrm{H},-\mathrm{OCH}_{3}\right)$, $4.01\left(\mathrm{~s}, 3 \mathrm{H},-\mathrm{OCH}_{3}\right), 3.28-3.34\left(\mathrm{~m}, 2 \mathrm{H},-\mathrm{CH}_{2}-\right), 3.18-3.22\left(\mathrm{~m}, 2 \mathrm{H},-\mathrm{CH}_{2^{-}}\right), 1.91-1.96\left(\mathrm{~m}, 2 \mathrm{H},-\mathrm{CH}_{2}-\right)$, 1.54-1.61 (m, 2H, - $\left.\mathrm{CH}_{2}-\right), 1.42-1.46\left(\mathrm{~m}, 4 \mathrm{H},-\mathrm{CH}_{2}-\right), 0.96\left(\mathrm{~s}, 3 \mathrm{H}, J=7.0 \mathrm{~Hz},-\mathrm{CH}_{3}\right)$; ESI-MS $m / z$ : 436.2 [M-Cl] ; Anal. calcd. for $\mathrm{C}_{27} \mathrm{H}_{34} \mathrm{ClNO}_{4} \times 1 / 2 \mathrm{H}_{2} \mathrm{O}: \mathrm{C} 67.42, \mathrm{H}$ 7.33, N 2.91; found: C 67.71, H $7.45, \mathrm{~N} 2.99$.

2,3-Dimethoxy-9,10-dimethoxy-13-n-octylprotoberberine chloride (4d). Yield 62\%; m.p. 175-177 ${ }^{\circ} \mathrm{C}$; ${ }^{1} \mathrm{H}-\mathrm{NMR}\left(\mathrm{CDCl}_{3}\right): \delta(\mathrm{ppm}) 10.83$ (s, 1H, Py-H), 7.85-7.89 (m, 2H, Ph-H), 7.19 (s, 1H, Ph-H), 6.91 (s, 1H, Ph-H), 5.21-5.26 (m, 2H, - $\left.\mathrm{CH}_{2}-\right), 4.33\left(\mathrm{~s}, 3 \mathrm{H},-\mathrm{OCH}_{3}\right), 4.07\left(\mathrm{~s}, 3 \mathrm{H},-\mathrm{OCH}_{3}\right), 3.98\left(\mathrm{~s}, 3 \mathrm{H},-\mathrm{OCH}_{3}\right)$, $3.92\left(\mathrm{~s}, 3 \mathrm{H},-\mathrm{OCH}_{3}\right), 3.25-3.31\left(\mathrm{~m}, 2 \mathrm{H},-\mathrm{CH}_{2}-\right), 3.18\left(\mathrm{~s}, 2 \mathrm{H},-\mathrm{CH}_{2^{-}}\right), 1.89-1.91\left(\mathrm{~m}, 2 \mathrm{H},-\mathrm{CH}_{2^{-}}\right), 1.51-1.54$ (m, 2H, $\left.-\mathrm{CH}_{2}-\right), 1.27-1.32\left(\mathrm{~m}, 8 \mathrm{H},-\mathrm{CH}_{2}-\right), 0.87$ (s, 3H, $\left.J=7.0 \mathrm{~Hz},-\mathrm{CH}_{3}\right)$; ESI-MS m/z: 464.2 [M-Cl] ${ }^{+}$; Anal. calcd. for $\mathrm{C}_{29} \mathrm{H}_{38} \mathrm{ClNO}_{4} \times \mathrm{H}_{2} \mathrm{O}: \mathrm{C} 67.23, \mathrm{H}$ 7.78, N 2.57; found: C 67.54, H 7.88, N 2.70.

\subsection{Pharmacology}

\subsubsection{MTT Assay}

The MTT [32] cell proliferation assay was used to test the antitumor activity of berberine, palmatine and compounds 4a-d. The cells were seeded in RPMI-1640 medium $(100 \mu \mathrm{L})$ in a $96-$ well plate at a concentration of 5000 cells per well. After culturing for $12 \mathrm{~h}$ at $37{ }^{\circ} \mathrm{C}$ and with $5 \% \mathrm{CO}_{2}$, cells were incubated with scalar concentrations of the tested compounds for $24 \mathrm{~h}$. MTT was added to the cultures at a final concentration of $5 \mu \mathrm{g} / \mathrm{mL}$, and incubated for $4 \mathrm{~h}$. The formazan crystals were formed and dissolved in DMSO $(100 \mu \mathrm{L})$ each well. The optical density was measured at $570 \mathrm{~nm}$ with the reference wavelength $630 \mathrm{~nm}$. All of the compounds were tested thrice independently using the same cell line. $\mathrm{IC}_{50}$ (concentration that inhibits $50 \%$ of cell growth) was calculated using the Bacus Laboratories Incorporated Slide Scanner (Bliss) software, and the data in this manuscript represent mean of two independent experiments.

\subsubsection{Anticancer Activity in Vivo}

Cyclophosphamide was supplied by Shanghai Hualian Pharmaceutical Co. Ltd. (Shanghai, China); Kunming mice weighing 19-21 g were received from the Shanghai Laboratory Animal Center (Shanghai, China) and kept at five mice/cage at $22-28{ }^{\circ} \mathrm{C}$ on a $12 \mathrm{~h} \mathrm{light/dark} \mathrm{cycle} \mathrm{with} \mathrm{food} \mathrm{and}$ water ad libitum. All animals were treated in accordance with the guidelines established by the Institutional Animal Care and Use Committee.

The S180 sarcoma tumor cells (supplied by the Pharmacology Laboratory of Shanghai Institute of Pharmaceutical Industry, Shanghai, China) were diluted with $0.9 \%$ normal saline solution to $1-2 \times 10^{7}$ cells $/ \mathrm{mL}$ and transplanted s.c. via trocar into the left armpits by using an aseptic 
manipulation, $0.2 \mathrm{~mL} /$ mouse. Cyclophosphamide, berberine, palmatine and compounds $4 \mathbf{a}-\mathbf{d}$ were rejected by the vein at various doses. Each mouse was weighed three times a week and at the end of the study; tumor was weighted by electron scales and tumor inhibition rate was calculated according to the following formula:

Tumor inhibition rate $=$ (mean tumor weight of negative group - mean tumor weight of treated group)/mean tumor weight of negative group $\times 100 \%$.

\subsubsection{Statistical Analysis}

All data are presented as mean \pm standard deviations (S.D.). The confidence limits were set at $p<0.05$. Statistical significance of the differences between groups was assessed by Student's $t$-test.

\section{Conclusions}

The present study to investigate the effect of various long carbon-chain subinstituts at the C-13-position of berberines and palmatines on antitumor activity was successfully carried out. The primary screening results indicated that 13 - $n$-octyl-palmatine (4d) displayed potent cytotoxic activity against seven cancer cells in vitro, but 13-n-hexyl-berberine (4c) exhibited better antitumor activity and less toxic effect in vivo. These studies may provide some guidances for the development of natural compounds as anticancer agents with potential clinical value. Further, structure-activity relation studies and mechanistic studies on this new class of berberine and palmatine compounds are currently in progress and will be reported in due course.

\section{Acknowledgments}

This study was supported by grant from National Natural Science Fund (No. 39870882) for financial assistance.

\section{References}

1. Rabbani, G.H.; Butler, T.; Knight, J.; Sanyal, S.C.; Alam, K. Randomized controlled trial of berberine sulfate therapy for diarrhea due to enterotoxigenic E. coli and Vibrio cholerae. J. Infect. Dis. 1987, 155, 979-984.

2. Zhou, H.Y.; Mineshita, S. The Effect of Berberine Chloride on Experimental Colitis in Rats In Vivo and In Vitro. J. Pharmacol. Exp. Ther. 2000, 294, 822-829.

3. Iwasa, K.; Kamigauchi, M.; Ueki, M.; Taniguchi, M. Antibacterial activity and tructure-activity relationships of berberine analogs. Eur. J. Med. Chem. 1996, 31, 469-478.

4. Samosorn, S.; Tanwirat, B.; Muhamad, N.; Casadei, G.; Tomkiewicz, D.; Lewis, K.; Suksamrarn, A.; Prammananan, T.; Gornall, K.C.; Beck, J.L.; et al. Antibacterial activity of berberine-NorA pump inhibitor hybrids with a methylene ether linking group. Bioorg. Med. Chem. 2009, 17, 3866-3872.

5. Park, K.D.; Lee, J.H.; Kim, S.H.; Kang, T.H.; Moon, J.S.; Kim, S.U. Synthesis of 13-(substituted benzyl) berberine and berberrubine derivatives as antifungal agents. Bioorg. Med. Chem. Lett. 2006, 16, 3913-3916. 
6. Iwasa, K.; Kim, H.S.; Wataya, Y.; Lee, D.U. Antimalarial activity and structure-activity relationships of protoberberine alkaloids. Eur. J. Med. Chem. 1998, 13, 65-69.

7. Vennerstrom, J.L.; Lovelace, J.K.; Waits, V.B.; Hanson, W.L.; Klayman, D.L. Berberine derivatives as antileishmanial drugs. Antimicrob. Agents Chemother. 1990, 34, 918-921.

8. Letasiová, S.; Jantová, S.; Cipák, L.; Múcková, M. Berberine-antiproliferative activity in vitro and induction of apoptosis/necrosis of the U937 and B16 cells. Cancer Lett. 2006, 239, 254-262.

9. Sun, Y.Y.; Xun, K.L.; Wang, Y.T.; Chen, X.P. A systematic review of the anticancer properties of berberine, A natural product from Chinese herbs. Anticancer Drugs 2009, 20, 757-769.

10. Tang, J.; Feng, Y.B.; Tsao, S.; Wang, N.; Curtain, R.; Wang, Y.W. Berberine and Coptidis Rhizoma as novel antineoplastic agents: A review of traditional use and biomedical investigations. J. Ethnopharmacol. 2009, 126, 5-7.

11. Li, X.K.; Motwani, M.; Tong, W.; Bornmann, W.; Schwartz, G.K. Huanglian, A Chinese Herbal Extract, Inhibits Cell Growth by Suppressing the Expression of Cyclin B1 and Inhibiting CDC2 Kinase Activity in Human Cancer Cells. Mol. Pharmacol. 2000, 58, 1287-1293.

12. Kim, S.; Choi, J.H.; Kim, J.B.; Nam, S.J.; Yang, J.H.; Kim, J.H.; Lee, J.E. Berberine Suppresses TNF- $\alpha$-induced MMP-9 and Cell Invasion through Inhibition of AP-1 Activity in MDA-MB-231 Human Breast Cancer Cells. Molecules 2008, 13, 2975-2985.

13. Jiang, H.L.; Wang, X.; Huang, L.; Luo, Z.H.; Su, T.; Ding, K.; Li, X.S. Benzenediol-berberine hybrids: Multifunctional agents for Alzheimer's disease. Bioorg. Med. Chem. 2011, 19, 7228-7235.

14. Ji, H.F.; Shen, L. Berberine: A Potential Multipotent Natural Product to Combat Alzheimer's Disease. Molecules 2011, 16, 6732-6740.

15. Bodiwala, H.S.; Sabde, S.; Mitra, D.; Bhutani, K.K. Synthesis of 9-substituted derivatives of berberine as anti-HIV agents. Eur. J. Med. Chem. 2011, 46, 1045-1049.

16. Hayashi, K.; Minoda, K.; Nagaoka, Y.; Hayashi, T.; Uesatob, S. Antiviral activity of berberine and related compounds against human cytomegalovirus. Bioorg. Med. Chem. Lett. 2007, 17, $1562-1564$.

17. Yang, P.; Song, D.Q.; Li, Y.H.; Kong, W.J.; Wang, Y.X.; Gao, L.M.; Liu, S.Y.; Cao, R.Q.; Jiang, J.D. Synthesis and structure-activity relationships of berberine analogues as a novel class of low-density-lipoprotein receptor up-regulators. Bioorg. Med. Chem. Lett. 2008, 18, 4675-4677.

18. Tang, L.Q.; Wei, W.; Chen, L.M.; Liu, S. Effects of berberine on diabetes induced by alloxan and a high-fat/high-cholesterol diet in rats. J. Ethnopharmacol. 2006, 108, 109-115.

19. Chen, W.H.; Pang, J.Y.; Qin, Y.; Peng, Q.; Cai, Z.; Jiang, Z.H. Synthesis of linked berberine dimers and their remarkably enhanced DNA-binding affinities. Bioorg. Med. Chem. Lett. 2005, 15, 2689-2692.

20. Franceschin, M.; Rossetti, L.; D’Ambrosio, A.; Schirripa, S.; Bianco, A.; Ortaggi, G.; Savino, M.; Schultes, C.; Neidle, S. Natural and synthetic G-quadruplex interactive berberine derivatives. Bioorg. Med. Chem. Lett. 2006, 16, 1707-1711.

21. Zhang, W.J.; Ou, T.M.; Lu, Y.J.; Huang, Y.Y.; Wu, W.B.; Huang, Z.S.; Zhou, J.L.; Wong, K.Y.; $\mathrm{Gu}$, L.Q. 9-Substituted berberine derivatives as G-quadruplex stabilizing ligands in telomeric DNA. Bioorg. Med. Chem. 2007, 15, 5493-5501.

22. Bbadra, K.; Kumar, G.S. Therapeutic Potential of Nucleic Acid-Binding Isoquinoline Alkaloids: Binding Aspects and Implications for Drug Design. Med. Res. Rev. 2011, 31, 821-862. 
23. Islam, M.M.; Basu, A.; Hossain, M.; Sureshkumar, G.; Hotha, S.; Kumar, G.S. Enhanced DNA Binding of 9- $\omega$-Amino Alkyl Ether Analogs from the Plant Alkaloid Berberine. DNA Cell Biol. 2011, 30, 123-133.

24. Islam, M.M.; Basu, A.; Kumar, G.S. Binding of 9-O-( $\omega$-amino) alkyl ether analogues of the plant alkaloid berberine to poly(A): Insights into self-structure induction. Med. Chem. Commun. 2011, 2, 631-637.

25. Basu, A.; Jaisankar, P.; Kumar, G.S. Synthesis of novel 9-O-N-aryl/aryl-alkyl amino carbonyl methyl substituted berberine analogs and evaluation of DNA binding aspects. Bioorg. Med. Chem. 2012, 20, 2498-2505.

26. Bhowmik, D.; Hossain, M.; Buzzetti, F.; D’Auria, R.; Lombardi, P.; Kumar, G.S. Biophysical Studies on the Effect of the 13 Position Substitution of the Anticancer Alkaloid Berberine on Its DNA Binding. J. Phys. Chem. B 2012, 116, 2314-2324.

27. Chang, Y.L.; Usami, S.; Hsieh, M.T.; Jiang, M.J. Effects of palmatine on isometric force and intracellular calcium levels of arterial smooth muscle. Life Sci. 1999, 64, 597-606.

28. Vennerstrom, J.L.; Klayman, D.L. Protoberberine Alkaloids as Antimalarials. J. Med. Chem. 1988, 31, 1084-1087.

29. Kuo, C.L.; Chou, C.C.; Yung, B.Y. Berberine complexes with DNA in the berberine-induced apoptosis in human leukemic HL-60 cells. Cancer Lett. 1995, 93, 193-200.

30. Iwasa, K.; Kamigauchi, M.; Sugiura, M.; Nanba, H. Antimicrobial Activity of Some 13-Alkyl Substituted Protoberberinium Salts. Planta Med. 1997, 63, 196-198.

31. Wei, H.L.; Wang, S.Q.; Xu, F.; Xu, L.F.; Zheng, J.R.; Chen, Y. Evaluation of a 13-hexylberberine hydrochloride topical gel formulation. Drug Dev. Ind. Pharm. 2012, 38, 1-6.

32. Skehan, P.; Storeng, R.; Scudiero, D.; Monks, A.; McMahon, J.; Vistica, D.; Warren, J.T.; Bokesch, H.; Kenney, S.; Boyd, M.R. New Colorimetric Cytotoxicity Assay for Anticancer-Drug Screening. J. Natl. Cancer. Inst. 1990, 82, 1107-1112.

Sample Availability: Contact the first author.

(C) 2012 by the authors; licensee MDPI, Basel, Switzerland. This article is an open access article distributed under the terms and conditions of the Creative Commons Attribution license (http://creativecommons.org/licenses/by/3.0/). 